\title{
POSTNATAL DEVELOPMENT OF THE INNER EAR EFFERENT INNERVATION IN MAMMALS
}

\author{
Emylian A. Ivanov', Svetla P. Doseva ${ }^{1}$ and Nikolai E. Lazarov ${ }^{2,3}$ \\ ${ }^{1}$ Department of Anatomy, Histology and Cytology, Medical University, Pleven, Bulgaria; ${ }^{2}$ Department \\ of Anatomy and Histology, Medical University, Sofia, Bulgaria; ${ }^{3}$ Institute of Neurobiology, Bulgarian \\ Academy of Sciences, Sofia, Bulgaria
}

Efferent innervation of the inner ear is extensively studied but the whole model revealing the development of efferent synapses is not clear yet. In mammals the lateral and medial olivocochlear systems are known as the source of efferent fibers. The lateral olivocochlear system innervates the ipsilateral cochlea, terminating on the dendrites beneath the inner hair cells (IHCs), the dendrites being spiral ganglion neuron compounds. The medial olivocochlear system is involved in forming synapses directly on the outer hair cells (OHCs). To reach the final targets efferent axons use the afferent fibers as a scaffold. Efferent synaptogenesis occurs just before the onset of hearing. At P0 in rats we observed synaptic-like contacts lacking typical features. At P3 the synapses were immature. At P4-P5 efferent contacts with IHCs were clearly defined. At P6 - P7 the efferent terminals were larger with distinct synaptic vesicles. During maturation, at P8 - P10, the number of efferent synapses at the base of the ICHs reduced alongside with a decrease in the synaptic cisternae. After P12 efferent terminals formed axodendritic synapses below IHCs and large axosomatic synapses on OHCs. The innervation of OHCs underwent two stages, i.e. transitional with simultaneous innervation of IHCs and $\mathrm{OHCs}$ and a final OHC-targeted innervation. These results support the idea for a waiting period of efferent innervation before its final establishment in adult organ of Corti. We also summarize the role of neurotrophic factors, specific neurotransmitter systems, their receptors and transporters for refinement of cochlear efferent innervation. Biomed Rev 2013; 24: 33-48

Key words: acetylcholine, cochlea, hair cells, olivocochlear, organ of Corti, rat

Received 5 December 2013, accepted 18 December 2013.

Correspondence to Dr Emylian A. Ivanov, Department of Anatomy, Histology and Cytology, Faculty of Medicine, Medical University, Pleven, 1 Sv Kliment Ohridski Str., BG-5800 Pleven, Bulgaria. Tel. +359-64-884 240,

E-mail: ahcb@mu-pleven.bg 


\section{INTRODUCTION}

The efferent innervation of the inner ear in vertebrates has been extensively studied (reviewed in 1) but still there is no complete and adequate model for its development. Despite the remarkable progress in our knowledge of the morphology, physiology and development of efferent neurons, their functional role remains enigmatic so far. At present, it is generally assumed that the efferent input exerts control over a number of functional aspects, i.e. acoustic range, sound localization, enhancement of nerve coding and a protection in acoustic trauma (2-5).

The auditory apparatus of all vertebrates receives efferent innervation originating in the so-called hindbrain octavolateralis efferent system (6). Similar to other sensory feedback systems, the efferent cochlear system receives information via ascending sensory fibers and sends projections to the cochlear nuclei and mechanosensory hair cells of the inner ear. The descending centrifugal pathway arises from neurons whose perikarya are located close to the brachial motor nuclei in the pons and medulla oblongata.

Studies on birds and mammals show that the efferent neurons of the inner ear share a common embryologic origin with the motoneurons of the facial nerve (7). During development the efferent neurons of the inner ear acquire a phenotype differing from the one of the motoneurons and give rise to contralateral axonal projections $(7,8)$. The peripheral projections of efferent neurons run parallel to the facial nerve fibers, join the vestibulocochlear nerve and make direct synaptic contacts upon the hair cells, or upon the dendrites of the ganglion cells right beneath the hair cells. The close apposition of the efferent neurons to the branchial motor nuclei in all vertebrates suggests that phylogenetically they derive from the motor column although they innervate neuroepithelium rather than muscles $(9,10)$.

In mammals the cochlear efferent neurons are located between the rostral pole of the facial motor nucleus and the lateral lemniscus, and are divided into two separate systems, i.e. a lateral and a medial olivocochlear (OC) system (11-13). The neurons of the lateral system are fusiform, small in size and contain acetylcholine (ACh) or $\gamma$-aminobutyric acid (GABA), either of them colocalized with calcitonin gene-related peptide (CGRP). They mainly project to the ipsilateral cochlea and make contacts with dendrites beneath the inner hair cells (IHCs), thus forming axodendritic synapses. According to their localization in the lateral OC system the neurons fall into two groups: intrinsic neurons, located in the superior olivary complex itself, and shell neurons which are found on its margins (14). Most of the fibers are large non-varicose axons and only $15 \%$ of them have varicosities of the boutons en passant type (9). The medial OC neurons are larger multipolar ones and produce ACh. They are primarily found in the rostral and ventral periolivary regions and project to the contralateral cochlea, making direct axosomatic synaptic contacts upon the outer hair cells (OHCs). Before leaving the brainstem both groups of efferent axons run across the internal genu of the facial nerve and join the vestibulocochlear nerve $(7,14)$.

\section{ACETYLCHOLINE IS THE MAIN NEUROTRANSMITTER OF THE COCHLEAR EFFERENT SYSTEM}

Acetylcholine (ACh) is a major neurotransmitter in synaptic communication between the efferent $\mathrm{OC}$ axons and the cochlear hair cells within the mammalian inner ear. Evidence for this comes from histochemical studies on its degrading and synthesizing enzymes, acetylcholinesterase (AChE) and choline acetyltransferase (ChAT), respectively $(15,16)$. In birds, ChAT immunoreactivity is found in two efferent cell populations, one located ventrolateral of the superior olivary complex and the other situated dorsomedially in the pontine reticular formation (17). In addition, ChAT immunoreactivity is described in the ventral periolivary region and the lateral superior olivary complex in mammals. Recent data suggest that all cholinergic cells in the lateral part of the superior olivary complex belong to the population of lateral OC neurons and only the larger cholinergic cells in the ventral nucleus of the trapezoid body belong to the medial OC neurons. The smaller-sized cholinergic neurons in the ventral nucleus of the trapezoid body most probably send efferent projections to the cochlear nuclei $(18,19)$. The efferent fibers in the avian inner ear do not express any other neurotransmitters or neuropeptides (16). In mammals, however, in addition to ACh-containing neurons, some GABA- and dopamine (DA)-immunopositive efferent perikarya and terminals have been shown. GABA and glutamic acid decarboxylase (GAD) immunoreactivity is demonstrated in efferent fibers beneath the IHCs. Moreover, GABA and GAD immunoreactivity has also been found in terminals below the OHCs mostly in the cochlear apical areas with a sparse medial OC innervation (20,21). GABA and GAD immunoreactivity has not been reported in the periolivary regions where the medial OC neurons are located, although by using retrograde tract-tracing experiments combined with immunohistochemistry such immunostaining is clearly observed in the lateral superior olive (22). 
Other neurochemical studies confirm the presence of several neuroactive substances including DA and the neuropeptides CGRP, enkephalin (ENK) and dynorphin (DYN). CGRP is usually colocalized with ACh in most motoneurons and so it can be assumed that it regulates the synthesis of ACh receptors. In some mammals, CGRP is colocalized with the cholinergic system in the lateral but not the medial OC neurons (19, 23-26). These neurotransmitters can further be functionally designated with respect to their effect on afferent dendrites. In particular, ACh, DYN and CGRP probably exert an excitatory effect, increasing depolarization of the hair cells and facilitating glutamate (GLU) release from the IHCs $(27,28)$. On the other hand, DA, ENK and GABA are inhibitory and suppress the GLU release from the IHCs $(29,30)$.

\section{MECHANISM OF ACETYLCHOLINE ACTION}

Acetylcholine is the main transmitter of the medial afferent fibers $(3,31)$. It evokes hyperpolarization of the OHCs via an activation of calcium-dependent small conductance (SK) potassium channels (32). The ACh receptor (AChR) is a ligandgated ion channel and a genetic homologue of nicotinic AChRs (nAChRs) in neurons and muscles.

In the organ of Corti the presynaptic depolarization induces an inhibitory hyperpolarization of the OHCs $(33,34)$. It is known that $\mathrm{nAChR}$ is a heteromer, made up of two $\alpha 9$ and three $\alpha 10$ subunits. ACh binds to $\alpha 9 / \alpha 10 \mathrm{nAChR}$ and causes calcium influx, which in turn leads to opening of the SK calciumactivated potassium channels and induces hyperpolarization. The calcium influx into the cell triggers calcium-dependent events with a subsequent release of the intracellular calcium stores from the synaptic cisternae of the OHCs (35). Similar to the sarcoplasmic reticulum in myocytes, the synaptic cisternae, structures thought to be homologous to the endoplasmic reticulum, cause calcium-induced calcium release (CICR), and as a result slow excitation turns into inhibition. The subsurface cisternae are seen inward of the postsynaptic membrane, at the level of the efferent contacts and are considered an invariable trait of the cholinergic synapses in hair cells.

Two major mechanisms for the release of calcium stores have been proposed: ryanodine receptor (RyR)- and inositol trisphosphate (IP3) receptor-mediated. Both receptor types are involved in the cholinergic mechanism of inhibition and depend on the $\mathrm{Ca}^{2+}$ influx. In case of activated $\mathrm{AChRs}$ the $\mathrm{Ca}^{2+}$ influx triggers the CICR system via RyRs in the membranes of the synaptic cisternae with a subsequent activation of the $\mathrm{SK}-\mathrm{Ca}^{2+}$ gated $\mathrm{K}+$ channels in the hair cell membranes (36).
A third possibility for $\mathrm{Ca}^{2+}$ release is suggested, namely via a direct interaction between the voltage-gated calcium channels (VGCCs) and the RyRs (37).

\section{ONSET OF THE EFFERENT TRANSMITTER EXPRESSION IN THE COCHLEA}

Not all neurotransmitters and modulators established in the efferent OC neurons are expressed in the organ of Corti during the postnatal period. Immunohistochemical data confirm the presence of ACh (25,38), GABA $(20,28,39)$, CGRP $(40,41)$ and ENK (3). Studies on ChAT, AChE, GABA and GAD immunoreactivity in the developing cochlea show that it is principally expressed prior to CGRP immunoreactivity and all these neuroactive substances are first localized in the area of IHCs before they are found below the OHCs. In the developing rat cochlea, ChAT immunoreactivity is seen prenatally, GABA is observed on the first postnatal day (P1) and CGRP is demonstrated approximately four days after birth (P4) in the area of IHCs (42-45). In the OHC area in the rat, ChAT immunoreactivity appears about three days after birth (P3), GABA around P9 and GAD around P16 $(42,44,45)$. In the mouse cochlea, the cholinergic fibers are seen underneath the IHCs on embryonic day 19 (E19) while CGRP immunoreactivity is manifested at birth (P0) and GABA/GAD around P2 $(46,47)$. Cholinergic fibers are evident about P4, CGRP on P6 and GABA/GAD on P10 under the OHCs in mice $(47,48)$. In hamsters, ChAT immunopositive fibers are seen beneath the IHCs on P2, while they are evident beneath the OHCs after P6 (49,50). The authors also find that CGRP immunostained fibers are under IHCs on P7 and under OHCs on P12. Provided that the presence of CGRP and GABA/GAD characterize the lateral efferent system, then these findings support the assumption that it matures notably at a later stage $(15,23-26,49,50)$.

Since CGRP is usually localized in the cholinergic neurons of the lateral OC system, studies on the developing cochlea further support the notion that the lateral OC efferent fibers reach the cochlea much later than hitherto believed (51). In the hamster, CGRP is expressed neither in the efferent perikarya nor in the efferent axons before the medial OC axons have accumulated below the IHCs (26). It is generally accepted that throughout the nerve system the initial expression of CGRP is associated with the establishment of synaptic contacts. Nonetheless, the absence of CGRP expression does not by all means show a lack of cholinergic lateral OC axons. CGRP expression is a marker of the efferents in the lateral OC system and it is always colocalized with ACh. The presence of CGRP in the 
cochlea is not found prior to P7 and it proves a later arrival of the lateral efferent fibers there. The appearance of CGRP beneath the OHCs coincides with the establishment of efferent synaptic contacts. It is suggested that CGRP is involved in the formation and maintenance of ACh synapses as it is in the case of the neuromuscular junctions (52).

\section{NEUROGENESIS OF THE EFFERENT INNERVATION IN THE ORGAN OF CORTI}

The molecular mechanisms directing the efferent axons to the inner ear are unknown. During the neuronal growth in the brainstem as well as for the period of the efferent synaptogenesis, various substances are transitionally expressed. These serve as markers for the events during development. Numerous studies demonstrate that the efferent OC neurons possess a multistage mode of growth and termination upon their cochlear targets (53). The earliest molecular events studied so far are associated with homeodomain transcription factors, Hox genes and Pax6 which are involved in the axial orientation, segmentation and planning of the rhombencephalon and the head. They control the positioning of the rhombomeres and otic placode, and also the interactions between the mesenchyme and epithelium in the otocyst, and probably determine the transformation of certain motoneurons into another specific phenotype (10).

The GATA family of zinc finger transcription factors is involved in the differentiation of the efferent neurons in the inner ear (54). In chickens, GATA-2 transitionally expresses during the translocation of the efferents across the median plane (55). Misrouted and aberrant efferent axons are found both in heterozygous and GATA-3 null mutant mice, which shows that GATA-3 takes part in the efferent axon orientation $(54,56)$. The first GATA-3lacZ positive efferent neurons are observed close to the inner genu of the facial nerve and the periolivary areas of the superior olivary complex (54). Similar results are reported in mutant mice for neurogenin 1 (NGN1) which is a proneural basic helix-loop-helix gene protein important for the determination of sensory neurons (57). The inner ear of mutant mice lacks sensory neurons and efferent innervation (58). In the NGN1 mutants, the efferent axons of the inner ear do not reach the cochlea, or else part of them joins the facial nerve.

Ephrin molecules are involved in directing the efferent axons during the establishment of contralateral projections. The ephrins (Eph) are a family of membrane receptors that are implicated in the orientation and fasciculation of axons (59). In birds, the EphA receptors are expressed in motoneurons of rhombomeres 4 and 5 . They also most probably contain the efferent neurons of the inner ear (60). Using EphB2 mutant mice, Cowan et al (61) demonstrate that the growth cones of the contralateral efferent axons do not find their way to the mid-sagittal plane. It seems that the absence of EphB receptors in the inner ear efferents causes a delay in the establishment of contralateral projections. In wild-type mouse embryos, an intense expression of EphB2 in the efferent axons and the facial motoneurons has been shown.

Synaptic formation is initiated by the expression of the growth-associated neuronal protein GAP-43 (neuromodulin, B-53, F11) and synaptophysin. GAP-43 immunoreactivity is observed in the growth cones and tips showing an axonal growth in the direction of their targets. In rats GAP-43 immunoreactivity is evident under the IHCs on E21 and persists until the second postnatal month $(62,63)$. In the time period from P5 to P14, GAP-43 immunostaining is already seen also below the OHCs. In addition, synaptophysin-immunopositive fibers and terminals are observed under the IHCs on P1 and P3, and under the OHCs on P4 and P6 (42). In the hamster cochlea, the obtained data are similar, i.e. during P2-P14 GAP-43 immunopositive fibers and terminals are registered under the IHCs, while between P5 and P14 they are found under the OHCs.

Synaptophysin is demonstrated after synaptic formation; it is associated with synaptic vesicles and is indicative for the synaptic function. The presence of synaptophysin proves the occurrence of vesicular synaptic endings and correlates with the arrival of contralateral OC terminals first under the IHCs and subsequently under the OHCs (52,64-66). Synaptophysin immunopositivity is observed in the IHCs on P5 and its intensity persists until $\mathrm{P} 14$ while in the OHCs the immunoreactivity increases after P9. The highest intensity of GAP-43 and synaptophysin immunoreactivity is observed between P5 and P9. This is the time period when a marked synaptic reorganization occurs and it is associated with the decrease in the efferent terminals under the IHCs and their increase under the OHCs. The established expression of GAP-43 and synaptophysin is in accordance with proposals of Simmons et al. (67) about an early innervation of the medial OC efferents, contrary to the classic view on the initial lateral efferent innervation.

\section{EFFERENT FIBER DIRECTING FACTORS}

Two neurotrophins, the brain-derived neurotrophic factor (BDNF) and neurotrophin-3 (NT-3), and their tyrosine kinase receptors TrkB and TrkC respectively are important for the survival of cochlear afferent neurons. These neurotrophins 
direct the course of fibers to the organ of Corti (68-76). It seems that the efferent fibers utilize the molecular signals that are characteristic of the afferent fibers as follows. Firstly, as reported in mice mutant for ligands or neurotrophin receptors, the efferent projections grow following the same ascending pathways as the afferent fibers (77-79). Secondly, the efferent fibers cannot reach the organ of Corti without afferent innervation although functionally intact neurotrophins are present (80). However, once having reached their synaptic targets around the hair cells, the efferent fibers start utilizing local molecular signals such as the extracellular glycoprotein tenascin-C, which plays a role for directing both the afferent and efferent fibers (81).

The interactions between neurotransmitters and their receptors on the hair cells and afferent dendrites also contribute for the synaptic formation $(24,82,83)$. For instance, the appearance of the $\alpha 9$ nicotine receptor subunit in the hair cells coincides with the efferent innervation and most probably is influenced by the arrival of efferent fibers (24). Additional data suggest, however, that the $\alpha 9$ expression reflects the maturation stage of the hair cells and is not influenced by efferent fibers (83).

At neurotrophic/neurotropic level, the BDNF-TrkB complex is proposed as candidates mediating the local efferent reorganization since the onset of their expression coincides with changes in the efferent innervation model $(75,84)$. Other candidates for the efferent modulation in the organ of Corti are NT-3 and its TrkC receptor. NT-3 is found in the sustentacular cells of the organ of Corti, in the cells of the greater epithelial ridge and the Deiters' cells (85). The interaction between TrkC on the efferent membranes and the NT-3-producing supporting cells could explain the attraction between developing efferents amongst the cells of the greater epithelial ridge and the Deiters' cells.

Although motoneurons depend on trophic factors, the efferents of the inner ear are relatively independent of neurotrophic signals (86-88). In chickens and rats some neurotrophins, such as the nerve growth factor (NGF) and BDNF, are expressed at the time when the efferent axons reach the developing otocyst and commence the formation of projections to the target sensor organs $(76,89)$. Data from studies in mice mutant for BDNF, NT-3 and their corresponding receptors TrkB and TrkC show a secondary effect on the efferent neurons $(7,85)$. Available evidence suggests that the afferent fibers serve as a useful substrate directing the efferent axons to their sensory targets. The results of these studies indicate that the growth of the efferent axons closely follows the afferents on their way to target fields. The reported findings in the brainstem confirm that the efferent axons use the afferents as a platform for reaching their final targets $(7,58,59)$.

\section{DEVELOPMENT OF EFFERENT INNERVATION}

The efferent synaptogenesis is a critical stage in cochlear maturation in birds and mammals. It occurs right before the onset of auditory function. It is known that in chickens the fibers of the efferent system reach the cochlea after E10 while in mice, rats and hamsters this happens about birth (2,52,90-95).

In Wistar rats on P0 in the space around the IHCs and amongst the epithelial cells of the greater epithelial ridge we find numerous nerve fibers. They possess small and diverse terminal profiles containing various in size synaptic vesicles. In the area of the IHCs these putative efferent fibers are located in the space next to the tight junctions and do not form typical synapses, all the more in the IHC cytoplasm no synaptic specializations are distinguished (Fig. 1A). Synapse-like contacts between the putative afferent and efferent profiles can be observed in the area of the inner spiral bundle. These contacts possess membrane thickenings and synaptic vesicles. Such synapse-like contacts have been described between the efferent fibers and the epithelial cell of the Kölliker's organ in mice (96).

On P3 the efferent endings are well differentiated although the synaptic contacts display traits of immaturity. The efferent terminals are numerous and contain clear vesicles some of which are dense-cored. No synaptic contacts between the IHCs and the efferent terminals are found despite their close proximity. Occasionally, postsynaptic cisternae and thickenings are described. Between the efferent endings and the afferent fibers morphologically distinct synapses with pre- and postsynaptic thickenings are seen (Fig. 1B-D). In the P0-P3 interval efferent fibers or synaptic contacts are not found at all near the bases of the OHCs or among the Deiters' cells.

In the time period P4-P5 the efferent contacts on the IHCs are clearly discernible and have the characteristics of maturity, i.e. osmiophilic thickenings in the pre- and postsynaptic membrane and the presence of a small postsynaptic cistern with a vacuolar size. On P4 the efferent terminals reach the base and the lateral surface of the OHCs and the first row of Deiters' cells. The efferent terminals have an irregular shape and are located among the afferent fibers, partially enveloped by the Deiters' cells. On P4 the afferent profiles are larger than the efferent ones and opposed to them synaptic bodies are found. The efferent endings contain clear synaptic vesicles and in principle they do not form synaptic contacts either with the base of the OHCs or the afferent fibers (Fig. 2A). 

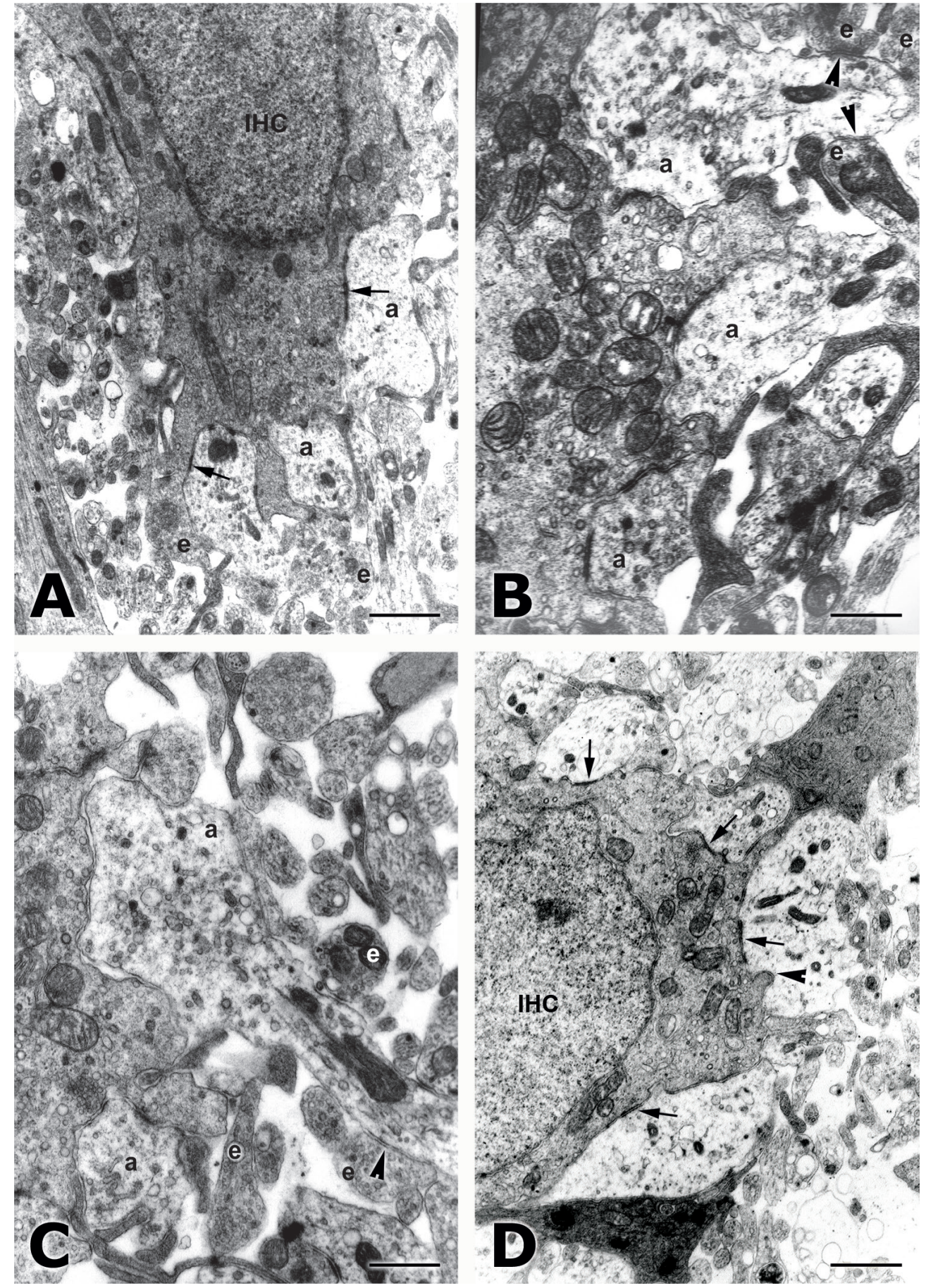

Figure 1. Patterns of efferent innervation in the rat cochlea on postnatal days 0 to 3 (P0-P3). (A). At P0 stage, some profiles of small-caliber nerve fibers which are presumable efferents and efferent boutons (e) are observed. Please note that the latter do not make synaptic specializations. Also note the afferent terminals (a) on the basolateral surface of an inner hair cell (IHC) form symmetrical synapses (arrows) with its cell body. (B) At this stage, the cell base is contacted by a number of large afferent terminals (a) and the efferent boutons (e) make contacts (arrowheads) with them. (C) Note that the efferent endings (e) are filled with numerous small clear and a few dense-cored synaptic vesicles, and some of them form contacts with afferent fibers (arrowhead). (D) Axosomatic (arrows) and axosomatic spine (arrowhead) synapses on the IHCs are also seen at P3 stage. Scale bars $=0.5 \mu \mathrm{m}$ in $(A, D), 0.75 \mu \mathrm{m}$ in $(B)$ and $1 \mu \mathrm{m}$ in $(C)$. 

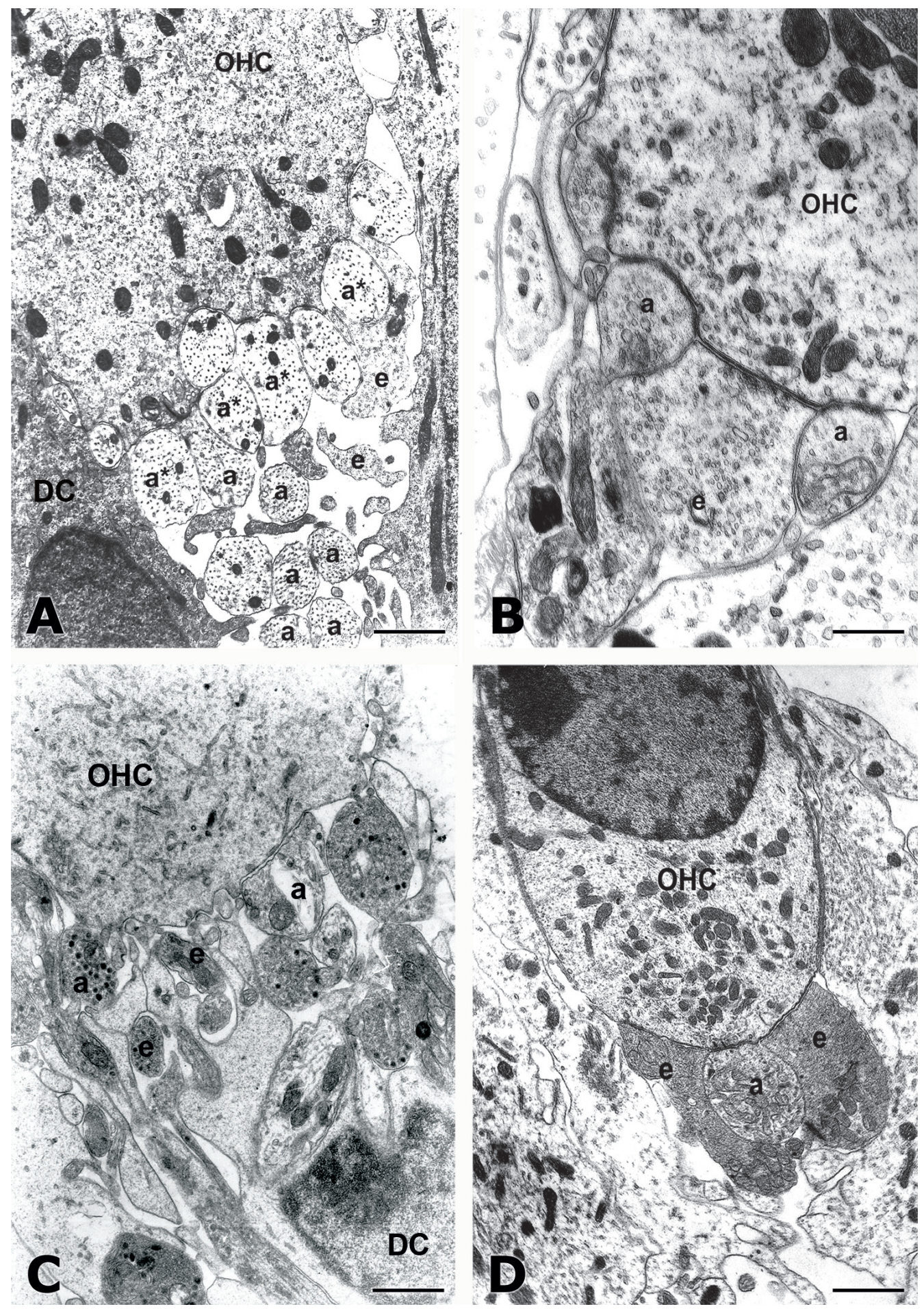

Figure 2. Pattern of efferent innervation in the rat cochlea at P4-P12 stage. (A) Spiral (a) and radial (a*) afferent fibers in somatodendritic synaptic contacts with the basal compartment of an outer cell hair (OHC) on P4. Note that the small efferent terminals (e) do not form synapses either with the OHC base or the afferent endings. (B) Somatodendritic (a) and axosomatic (e) synaptic contacts on an OHC on P7. (C) Afferent (a) and efferent (e) synapses on an OHC on P9. (D) A segment of the base of an OHC contacted by two large efferent terminals (e) and one small afferent bouton (a) at P12 stage. DC, Deiters'cell. Scale bars = $0.75 \mu \mathrm{m}$ in $(A, C)$, and $1 \mu \mathrm{m}$ in $(B, D)$. 
On P6-P7 several efferent contacts and a number of afferents are observed on the base of the IHCs. On P6 the efferent terminals are larger in size, containing more synaptic vesicles and mitochondria. They occupy most of the base of the OHCs and already outnumber the efferent endings. One subsynaptic cistern is positioned parallel to the postsynaptic membrane (Fig. 2B).

Later in time, on P8-P10, in Wistar rats the number of efferent synapses on the base of the IHCs decreases and simultaneously the postsynaptic specializations (i.e. the cisternae) are also reduced. About P9 efferent boutons on the second and third row of the OHCs are seen. They are always found alongside the basal aspect and are usually of a large size (Fig. 2C). After P12 the efferent endings form axodendritic synapses, although they are not seen on the cell bodies of the IHCs. Also after P12, the efferents form large terminals upon the OHCs and they occupy the synaptic surface of these cells (Fig. 2D). During this time occasional afferent endings are noted mostly in the apical parts of the cochlea.

Very rarely in serial sections from adult rats reappearing axosomatic synapses are described (97). These are also seen in experiments where the IHCs separate from the cochlear dendrites following excitotoxic damage $(98,99)$. Such observations confirm the theory that information to the IHCs from cholinergic efferents is absolutely necessary both in establishing the definitive model during development and in repair following injury.

Direct axosomatic contacts between the medial efferent endings and the basal aspects of the hair cells do not form before the onset of auditory function although efferent fibers can be found in the area beneath the OHCs several days earlier. Typical efferent synapses with well-defined postsynaptic cisternae are not observed before the second postnatal week in mice and rats $(100,101)$, E55 in guinea pigs (102) and the $22^{\text {nd }}$ week in the human fetus $(103,104)$. In all species, the formation of medial efferent synapses with the OHCs immediately precedes or overlaps with the onset of auditory function although there exists no direct relation between the development of efferents and the trigger mechanism for auditory sensation. Reaching the maturity stage of the efferent synapses is the final event in maturation of sensory and cochlear nerve structures (105). The immunological and tracing methods prove that the arrival of the efferent axons to cochlear structures is much earlier than hitherto believed $(50,106,107)$.

Anterograde tracing experiments with the fluorescent carbocyanine dye DiI show that the majority of the fibers initially contacting the IHCs belong to the crossed OC tract, and are probably terminals of medial OC neurons. This is contrary to the general belief that the lateral OC neurons are the first ones that form synapses in the cochlea (42). Such a novel viewpoint is based on the ultrastructural data obtained from newborn animals demonstrating efferent synapses beneath the IHCs (108). Studies by Simmons et al. (106) in hamsters suggest that these are various fiber types projecting to the organ of Corti at different developmental stages. Extracellular injecting with horseradish peroxidase (HRP) in the vestibulocochlear nerve displays a population of fibers without vesicles which directly terminate on the IHCs in the first three postnatal days. At later developmental stages the same technique reveals that these fibers contact both the IHCs and OHCs. With age the labeled fibers are found only on the OHCs similar to the model in adult animals. Cole and Robertson (109) report dense projections to the IHCs on P1-P2 and to the OHCs on P4-P6 after injecting DiI in sectioned crossed OC fibers in the rhomboid fossa of neonatal rats. These results verify that the crossed OC fibers wait under the IHCs for a certain period before their termination on the OHCs (Fig. 3). Since it is not possible to identify the synaptic specializations, it is still debatable whether the crossed OC fibers form true synapses on the IHCs or whether they only wait a few days before they reach their final targets. Our ultrastructural data demonstrate that some profiles of $\mathrm{OC}$ terminals contain vesicles and make direct contacts with the cell bodies of the IHCs. Probably, the crossed OC fibers form functional synapses on the IHCs, so this explains the contradictory effects of the early efferent stimulation (44).

The occurrence of labeled terminals of the crossed OC bundle beneath the IHCs does not exclude the possibility for the presence of ipsilateral fibers. Studies show that the lateral OC neurons send projections to the cochlea simultaneously with the medial ones (49). Using fluorescent tracer techniques it was demonstrated that the both types of OC fibers are present in the cochlea of newborn rats (53). The notion for a waiting period is supported by data on expression changes in growth-associated and synapse-associated proteins. Results from immunohistochemical experiments are in agreement with these obtained with axonal tract tracing techniques suggesting that the first efferent axons accumulate under the IHCs and then project to the first row of OHCs (107). Ultrastructural observations on P0 indicate that both the labeled efferent and unlabeled putative afferent contacts upon the IHCs possess features typical of immature synapses, such as few irregularly sized vesicles and some mitochondria. In rats the efferent ter- 

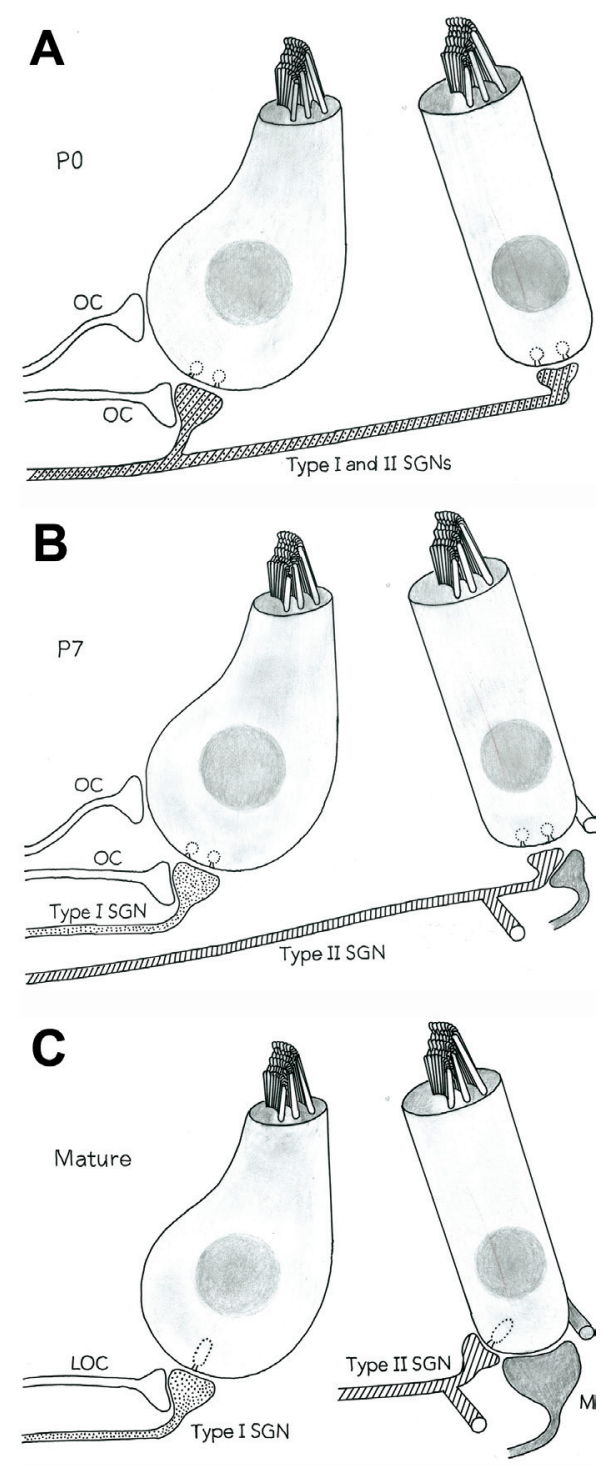

Figure 3. Schematic drawing of IHC and OHC synaptogenesis. The afferent fibers are shown by hatched contour lines and the efferent ones by gray (to OHCs) and white (to IHCs) profiles. (A) At the stage of immaturity (PO) the radial afferent fibers containing numerous synaptic vesicles establish multiple contacts with the IHCs. At this initial stage, the immature OHCs are innervated only by afferent fibers (probably branches of the radial afferent or spiral fibers - type I and type II SGN innervation). (B) During the intermediate stage (P7) the efferent fibers start making typical axosomatic synapses with OHCs. (C) At the stage of maturity the efferent fibers from medial olivocochlear (MOC) neurons form axosomatic synapses with OHCs while axodendritic efferent contacts from lateral OC (LOC) neurons are formed below IHCs. SGN, spiral ganglion neuron. Modified from Bulankina and Moser (95). minals on the IHCs decrease between P2 and P4 while efferent terminals appear beneath the OHCs. The majority though not all efferent projections reach the OHCs just prior to opening of the tunnel of Corti (106).

The innervation of the IHCs undergoes two stages, i.e. a transitory stage of double innervation of the IHCs and OHCs, and a final stage of individual $\mathrm{OHC}$ innervation (Fig. 3). The transitory stage coincides with the decrease in efferent contacts on the IHCs and the increase in efferent terminals on the first row of the OHCs (106). The mechanisms involved during the period of synaptic rearrangement from IHCs to OHCs are still unknown. A hypothesis on the competitive principle in the behavior of the afferent and efferent terminals for the space beneath the OHCs could explain the arrival of the efferent terminals which takes place simultaneously with a decrease in the afferents. This statement suggests that the afferent axons are the platform or framework facilitating the completion of the embryonic development of the efferent axons (110).

Unlike previous assumptions about the efferent innervation of the inner ear during development, it is now believed that the efferent axons of the medial OC neurons reach the IHCs on E12 and are the first predominantly cholinergic efferents to appear (111). Simmons et al. (5) suggest that the medial OC neurons share a common model of development similar to most motoneurons. They produce ACh before reaching their final targets of innervation and undergo notable synaptic rearrangement after making the initial contacts. The authors assume that the lateral OC neurons possess a far more selective model of development as they synthesize neurotransmitters after establishing final innervation (5). They tend to preserve their initial contacts during development.

The developmental stages of the medial cholinergic efferent fibers are as follows: 1) The medial OC neurons develop simultaneously with the facial motoneurons; 2) Similar to motoneurons they start ACh synthesis after their last mitotic division; 3) Unlike motoneurons, the guidance of efferent fibers occurs alongside the afferent axons; 4) The medial OC efferent fibers supply the IHCs during the so-called waiting period in development similar to the thalamocortical projections; 5) They exert transitory cholinergic suppression of the IHCs response; 6) The medial OC efferent fibers project predominantly to the first row of the $\mathrm{OHCs}$ prior to the opening of the tunnel of Corti; 7) The fibers initiate cholinergic responses from the OHCs which causes changes in the motility of the latter. All data confirm that the medial efferent system gains maturity before the onset of acoustic function (95). 
The cholinergic lateral OC neurons develop several days later than the medial ones. First, they begin their ACh synthesis after contacting the postsynaptic targets. Second, apart from ACh these neurons contain neuropeptides. Third, they do not undergo notable synaptic rearrangement at least in the basal end of the cochlea.

All these conclusions raise many issues regarding the molecular mechanisms which involve the direction of the efferent fibers, the waiting period beneath the IHCs and the synaptic rearrangement. It is believed that disclosing the mechanisms of efferent synaptogenesis and remodeling of the inner ear will also clarify the role of the cellular environment and molecular programming of the developing OC axons.

\section{MATURATION OF EFFERENT NEUROTRANSMISSION}

Efferent inhibition is facilitated by nAChR and via them $\mathrm{Ca}^{2+}$ influx occurs activating $\mathrm{Ca}^{2+}$-dependent SK potassium channels $(111,112)$. Due to the combined activity between the activation of the SK potassium channels and nAChR opening in the cholinergic response of the hair cells, the changes in their interactions could be a developmental indicator. The mature nAChR consists of an $\alpha 9$ subunit and an $\alpha 10$ nicotinic subunit (34). The two nicotinic subunits, $\alpha 9$ and $\alpha 10$, are expressed in the cochlear hair cells (113). Although the $\alpha 10$ subunit cannot form a functional receptor on its own, collectively the $\alpha 9$ and $\alpha 10$ subunits generate a hundred times more powerful flow than the homomeric $\alpha 9$ receptors. The homomeric $\alpha 9$ and the heteromeric $\alpha 9$ and $\alpha 10 \mathrm{nAChRs}$ possess similar pharmacological effects but different biophysical characteristics.

The transitory cholinergic innervation of the IHCs suggests that they express nAChRs. In rats and mice a transitional expression of $\alpha 9$ transcripts is also observed, at the time of development of the immature IHCs (83). Also, in situ hybridization experiments demonstrate the presence of $\alpha 9$ mRNA on E18 and the highest expressional levels are observed close to the IHCs while on P10 these are seen near the OHCs. Such studies show that the expression of $\alpha 9$ mRNA keeps a longitudinal, i.e. from base to apex, and a radial, i.e. from IHCs to OHCs, gradient. The $\alpha 10$ subunit is also expressed during development both in the IHCs and OHCs. However, they stop expressing $\alpha 10$ mRNA about the onset of hearing and they continue expressing only $\alpha 9$ mRNA until adulthood (111). Morley and Simmons (113) find a peak in the expression of $\alpha 10$ messages around P1 in the IHCs and another peak on P10 in the OHCs. Although $\alpha 9$ expression is observed early, on E18, in the cochlea, $\alpha 10$ expression is not detected prior to E21. Unlike the presence of $\alpha 9 \mathrm{mRNA}, \alpha 10 \mathrm{mRNA}$ is not found in the greater epithelial ridge at embryonic or neonatal age. Morley and Simmons (113) also report the loss of $\alpha 10$ expression in the rat IHCs on P21 although they show it in the OHCs. These findings confirm a different expressional pattern for $\alpha 10$ from that of $\alpha 9$ subunits in rats. It can be inferred from these data that the $\alpha 9$ and $\alpha 10$ subunits are differently regulated during the pre- and postnatal development. The mechanism by which the efferent axons contribute for the expression and localization of $\alpha 9$ and $\alpha 10$ nAChRs in the hair cells still remains unclear. In general, the decrease in postsynaptic receptors means a retraction of axonal branches while their increase is indicative for the appearance of new ones. Provided that the changes in the levels of $\alpha 9$ and $\alpha 10$ mRNA expression reflect synaptic plasticity, then the medial OC axons are capable of establishing alternating contacts with the hair cells.

The results of Katz et al. (114) show that on P16 the IHCs lose their functional nAChRs. This coincides with the termination of the $\alpha 10$ gene expression. After P16, the IHCs possess few or no axosomatic efferent synapses (115). Due to this a causative correlation between the $\alpha 10$ receptor expression and the establishment of efferent innervation is suggested. Similar to other nAChRs, the cochlear $\alpha 9$ and $\alpha 10 \mathrm{nAChR}$ could be involved in the regulation of gene expression, neuronal tracing, and synapse formation and stabilization (116). The efferent innervation of the IHCs is lost after the onset of the cochlear function on P12. Namely this is the time period when a constant transmission toward the CNS is registered. The event is marked by dramatic modifications in the expression of various ion channels such as disappearance of voltagedependent calcium and sodium channels (117), appearance of voltage-gated potassium currents utilizing large-conductance calcium-activated potassium channels (118). As a result, the IHCs stop generating calcium action potentials and evoke linear responses to sound stimulation.

The expression of functional cholinergic receptors and functional SK channels as well as the presence of functional axosomatic synapses also influence the ultrastructural patterns of the postsynaptic specializations. The concept of transitory cholinergic innervation is supported by pharmacological experiments which demonstrate the presence of $\alpha 9$ or $\alpha 9$ and $\alpha 10$ receptors in immature IHCs (112). The application of ACh in IHCs in the apical turn of the rat cochlea results in the activation of SK calcium-dependent potassium channels. It is obvious that the synaptic current and the ACh response are facilitated by nicotinic receptors with $\alpha 9$ pharmacological 
pattern. The cholinergic inhibition of the IHCs most probably contributes to the maturation of these cells, and the acoustic function. Several studies report that the immature IHCs repeatedly generate slow calcium action potentials $(112,118)$. Because of the generated action potentials with low frequency in the cochlear nerve during development, the cholinergic inhibition of the IHCs most probably invokes a rhythmic pattern in the auditory pathway $(112,111,119)$. The notion that the early presence of cochlear efferents is of importance for the normal maturation of the afferent response is also supported by experiments following ablation or efferent projection stimulation during the early postnatal period. In adult animals, the stimulation of efferent neurons results in suppressing the response of the cochlear nerve. Such an efferent-induced suppression is facilitated by the cross projections of the medial OC axons to the OHCs (120). In cats, the electric stimulation of the crossed efferent fibers on P9 or at a later age suppresses the action potentials. Initially, it was believed that the axodendritic lateral efferent terminals on the IHCs were responsible for this effect but later the medial efferent terminals and their impact on the IHCs were assumed to be the causative factors. In this period the efferent terminals on the OHCs are few in number. After de-efferentation, the most notable deficit is related to fewer spontaneous action potentials in the cochlear nerve (121). Unlike de-efferentated adult cats, neonatal de-efferentation gives effects such as changes in the cochlear nerve response with a higher threshold, decrease in the tuning precision and a lower spontaneous electrophysiological activity. These conclusions are truly valid only if the role of the OHCs is almost ignored. Despite all uncertainty the interaction between the efferent neurons and their postsynaptic targets plays a key role for the maturation of the active mechanical events in the inner ear.

\section{CHOLINE TRANSPORTERS}

The choline transporters play an important role in the ACh metabolism. In the rodent cochlea, two isoforms of the the high-affinity choline transporter (ChT1) are described: a nonglycosylated $73 \mathrm{kD}$ protein and a glycosylated $45 \mathrm{kD}$ protein. They are expressed by neurons in ventral periolivary regions of the brainstem superior olivary complex where the medial OC neurons are located. In older rats, ChT1-positive terminals are detected predominantly below OHCs consistent with a medial OC innervation (122). Between P2 and P4, ChT1-positive terminals are seen below IHCs demonstrated by the expression of GAP-43, synapsin and the vesicular acetylcholine transporter (VAChT). By P15, ChT1-immunostained terminals are mostly observed on OHCs (122). Based on these studies, it has been proposed that the initial ChT1expression occurs below IHCs and overlaps the expression patterns of other presynaptic and cholinergic markers such as synapsins and VAChT. In addition it is believed that in the mouse, but not in the rat, ChT1 may preferentially identify medial OC neurons (122), prior to contacting their final targets, i.e. the OHCs. This period of differentiation is now defined as a target-independent differentation period, previously termed a developmental waiting period. All these findings lead to the hypothesis that high affinity choline transport may be the final stage of cholinergic presynaptic differentiation occurring without the influence of the target (122).

The expression level of ChT1 by lateral efferent neurons is low in contrast to the higher expression patterns of ChAT, AChE and VAChT. The fast synaptic transmission requires a high-affinity choline transporter for rapid $\mathrm{ACh}$ synthesis. The absence of ChT1 or its low levels in the lateral OC neurons suggest that they are not involved in cholinergic fast synaptic transmission. It can be inferred that the final stage of efferent fiber maturation is marked by temporal expression of ChT1 $(26,123)$.

\section{CONCLUSION}

Recent advances in the cochlear research during postnatal development have revealed that the establishment of efferent innervation in the mammalian cochlea is characterized by transitory stages of abundant branching, elimination and remodeling of the synaptic contacts. The formation of the efferent circuitry begins at a very early stage, well before detection of morphologically distinct hair cells in the undifferentiated organ of Corti. The arrival of efferent fibers, which are axons of OC neurons, and synaptic formation are initiated and directed by growth factors and synaptophysin. At birth, axosomatic and axodendritic efferent synapses can be observed only around IHCs, whereas OHCs are devoid of efferent innervation. After a transient stage with abundant axosomatic efferent synapses on IHC, finally they are eliminated and axodendritic efferent contacts from lateral OC neurons are formed below IHCs. On the other hand, cholinergic axons from medial OC neurons make axosomatic synapses with OHCs. ACh is the primary efferent neurotransmitter of the cochlear system acting through nicotinic AChRs. The final stage of cholinergic differentiation of presynaptic efferent terminals in the inner ear is the expression of its high-affinity transporter. The onset of efferent synaptic function in hair cells requires 
an activation of calcium-dependent SK potassium channels. The maturation of efferent innervation involves subsequent refinement of neuronal circuitry during which inappropriate connections are eliminated.

\section{ACKNOWLEDGEMENTS}

The authors thank Dr Angel Dandov for critical reading of the manuscript.

\section{REFERENCES}

1. Guinan JJJ. Cochlear efferent innervation and function. Curr Opin Otolaryngol Head Neck Surg 2010; 18: 447453.

2. Pujol R. Synaptic plasticity in the developing cochlea. In: Ruben RJ, Van de Water TR, Rubel EW, editors. The Biology of Change in Otolaryngology. Elsevier, Amsterdam, 1986; 47-54.

3. Eybalin M. Neurotransmitters and neuromodulators of the mammalian cochlea. Physiol Rev 1993; 73: 309-373.

4. Liberman MC, Kujawa SG. The olivocochlear system and protection from acoustic injury: acute and chronic effects. In: Berlin CI, editor. The Efferent Auditory System: Basic Science and Clinical Applications. Singular Publishing Group, San Diego, 1999; 1-29.

5. Simmons D, Duncan J, Crapon de Caprona D, Fritzsch B. Development of the inner ear efferent system. In: Ryugo DK, Fay RR, Popper AN, editors, Auditory and Vestibular Efferents. Springer, New York: 2011: 187-216.

6. Robert BL, Meredith GE. The efferent innervation of the ear: variations on an enigma. In: Webster DB, Fay R, Popper AN, editors. The Evolutionary Biology of Hearing. Springer-Verlag, New York, 1992: 185-210.

7. Fritzsch B. Ontogenetic and evolutionary evidence for motoneuronal nature of vestibular and cochlear efferents. In: Berlin CI, editor. The Efferent Auditory System: Basic Science and Clinical Applications. Singular Publishing Group, San Diego, 1999: 31-60.

8. Fritzsch B. Development of the labyrinthine efferent system. Ann NY Acad Sci 1996; 781: 21-33.

9. Warr WB, Boche JB, Neely ST. Efferent innervation of the inner hair cell region: origins and terminations of two lateral olivocochlear systems. Hear Res 1997; 108: 89-111.

10. Sharma K, Leonard AE, Lettieri K, Pfaff SL. Genetic and epigenetic mechanisms contribute to motor neuron pathfinding. Nature 2000; 406: 515-559.

11. Guinan JJJ, Warr WB, Norris BE. Differential olivocochlear projections from lateral versus medial zones of the superior olivary complex. J Comp Neurol 1983; 221: 358-370.

12. Brown MC. Anatomy of olivocochlear neurons. In: Ryugo DK, Fay RR, Popper AN, editors. Auditory and Vestibular Efferents. Springer, New York, 2011; 17-38.

13. Lauer AM, Fuchs PA, Ryugo DK, Francis HW. Efferent synapses return to inner hair cells in the aging cochlea. Neurobiol Aging 2012; 33: 2892-2902.

14. Vetter DE, Mugnaini E. Distribution and dendritic features of three groups of rat olivocochlear neurons. A study with two retrograde cholera toxin tracers. Anat Embryol 1992; 185: 1-16.

15. Simmons DD, Bertolotto C, Kim J, Raji-Kubba J, Mansdorf $\mathrm{N}$. Choline acetyltransferase expression during a putative development waiting period. J Comp Neurol 1998; 397: 281-295.

16. Zidanic M. Cholinergic innervation of the chick basilar papilla. J Comp Neurol 2002; 445:1 59-175.

17. Code RA, Carr CE. Choline acetyltransferase-immunoreactive cochlear efferent neurons in the chick auditory brainstem. J Comp Neurol 1994; 340: 161-173.

18. Yao W, Godfrey DA. Immunohistochemical evaluation of cholinergic neurons in the rat superior olivary complex. Microsc Res Tech 1998; 41: 270-283.

19. Moore JK, Simmons DD, Guan Y. The human olivocochlear system: organization and development. Audiol Neurootol 1999; 4: 311-325.

20. Eybalin M, Parnaud C, Geffard M, Pujol R. Immunoelectron microscopy identifies several types of GABAcontaining efferent synapses in the guinea-pig organ of Corti. Neuroscience 1988; 24: 29-38.

21. Dannhof BJ, Roth B, Bruns V. Anatomical mapping of the choline acetyltransferase (ChAT)-like and glutamate decarboxylase (GAD)-like immunoreactivity in outer hair cell efferents in adult rats. Cell Tissue Res 1991; 266: 89-95.

22. Vetter DE, Adams JC, Mugnaini E. Chemically distinct rat olivocochlear neurons. Synapse 1991; 7: 21-43.

23. Simmons DD, Raji-Kubba J, Popper P, Micevych PE. Developmentally regulated expression of calcitonin generelated peptide in the superior olive. J Comp Neurol 1997; 377: 207-216.

24. Simmons DD, Morley BJ. Differential expression of the alpha 9 nicotinic acetylcholine receptor subunit in neonatal and adult cochlear hair cells. Brain Res Mol Brain Res 1998; 56: 287-292. 
25. Simmons DD, Bertolotto C, Typpo K, Clay A, Wu M. Differential development of cholinergic-like neurons in the superior olive: a light microscopic study. Anat Embryol (Berl) 1999; 200: 585-595.

26. Raji-Kubba J, Micevych PE, Simmons DD. Superior olivary complex of the hamster has multiple periods of cholinergic neuron development. J Chem Neuroanat 2002; 24: 75-93.

27. Felix D, Ehrenberger K. The efferent modulation of mammalian inner hair cell afferents. Hear Res 1992; 64: 1-5.

28. Maison SF, Emeson RB, Adams JC, Luebke AE, Liberman MC. Loss of alpha CGRP reduces sound-evoked activity in the cochlear nerve. J Neurophysiol 2003; 90: 2941-2949.

29. Malgrange B, Rigo JM, Lefebvre PP, Coucke P, Goffin F, Xhauflaire G, et al. Diazepam-insensitive GABAa receptors on postnatal spiral ganglion neurones in culture. Neuroreport 1997; 8: 591-596.

30. Sun W, Salvi RJ. Dopamine modulates sodium currents in cochlear spiral ganglion neurons. Neuroreport 2001; 12: 803-807.

31. LePrell CG, Bledsoe SCJ, Bobbin RP, Puel JL. Neurotransmission in the inner ear: Functional and molecular analyses. In: AF Jahn, J Singular, editors. Physiology of the Ear. 2nd. Ed., Santos-Sacchi, San Diego, 2001: 575-611.

32. Erostegui C, Norris CH, Bobbin RP. In vitro pharmacologic characterization of a cholinergic receptor on outer hair cells. Hear Res 1994; 74: 135-147.

33. Oliver D, Klocker N, Schuck J, Baukrowitz T, Ruppersberg JP, Fakler B. Gating of $\mathrm{Ca}^{2+}$-activated $\mathrm{K}^{+}$channels controls fast inhibitory synaptic transmission at auditory outer hair cells. Neuron 2000; 26: 595-601.

34. Elgoyhen AB, Vetter DE, Katz E, Rothlin CV, Heinemann SF, Boulter J. $\alpha 10$ : A determinant of nicotinic cholinergic receptor function in mammalian vestibular and cochlear mechanosensory hair cells. Proc Natl Acad Sci USA 2001; 98: 3501-3506.

35. Evans MG, Lagostena L, Darbon P, Mammano F. Cholinergic control of membrane conductance and intracellular free $\mathrm{Ca}^{2+}$ in outer hair cells of the guinea pig cochlea. Cell Calcium 2000; 28: 195-203.

36. Taylor CW, Laude AJ. IP3 receptors and their regulation by calmodulin and cytosolic $\mathrm{Ca}^{2+}$. Cell Calcium 2002; 32: 321-334.

37. O’Brien JJ, Feng W, Allen PD, Chen SR, Pessah IN, Beam KG. $\mathrm{Ca}^{2+}$ activation of RyR1 is not necessary for the initiation of skeletal-type excitation-contraction coupling.
Biophys J 2002; 82: 2428-2435.

38. Phelps PE, Brennan LA, Vaughn JE. Generation patterns of immunocytochemically identified cholinergic neurons in rat brainstem. Brain Res Dev Brain Res 1990; 56: 63-74.

39. Maison SF, Rosahl TW, Homanics GE, Liberman MC. Functional role of GABAergic innervation of the cochlea: phenotypic analysis of mice lacking GABA(A) receptor subunits alpha 1 , alpha 2 , alpha 5 , alpha 6 , beta 2 , beta 3 , or delta. J Neurosci 2006; 26; 10315-10326.

40. Micevych PE, Kruger L. The status of calcitonin generelated peptide as an effector peptide. Ann NY Acad Sci 1992; 657: 379-396.

41. Simmons DD, Raji-Kubba. Postnatal calcitonin generelated peptide in the superior olivary complex. J Chem Neuroanat 1993; 6: 407-418.

42. Gil-Loyzaga PE, Pujol R. Synaptophysin in the developing cochlea. Int J Dev Neurosci 1988; 6: 155-160.

43. Merchan-Perez A, Gil-Loyzaga P, Eybalin M. Immunocytochemical detection of calcitonin gene-related peptide in the postnatal developing rat cochlea. Int J Dev Neurosci 1990; 8: 603-612.

44. Merchan-Perez A, Gil-Loyzaga P, Eybalin M. Ontogeny of glutamate decarboxylase and gamma-aminobutyric acid immunoreactivities in the rat cochlea. Eur Arch Otorhinolaryngol 1990; 248: 4-7.

45. Merchán-Pérez A, Gil-Loyzaga P, Eybalin M, Fernández Mateos P, Bartolomé MV. Choline-acetyltransferase-like immunoreactivity in the organ of Corti of the rat during postnatal development. Brain Res Dev Brain Res 1994; 82: 29-34.

46. Whilton DS, Sobkowicz HM. GABA-like immunoreactivity in the cochlea of the developing mouse. J Neurocytol 1989; 18: 505-518.

47. Sobkowicz HM. The development of innervation in the organ of Corti. In: Romand R, editor. Development of Auditory and Vestibular Systems, Elsevier, Amsterdam, 1992; 2: 59-100.

48. Nitecka LM, Sobkowicz HM. The GABA/GAD innervation within the inner spiral bundle in the mouse cochlea. Hear Res 1996; 99: 91-105.

49. Simmons DD, Moulding HD, Zee D. Olivocochlear innervation of inner and outer hair cells during postnatal maturation: an immunocytochemical study. Brain Res Dev Brain Res 1996; 95: 213-226.

50. Simmons DD, Mansdorf N, Kim JH. Olivocochlear innervation of inner and outer hair cells during postnatal 
maturation: evidence for a waiting period. J Comp Neurol 1996; 370: 551-562.

51. Safieddine S, Eybalin M. Triple immunofluorescence evidence for the coexistence of acetylcholine, encephalin, and calcitonin gene-related peptide within efferent neurons of rats and guinea pigs. Eur J Neurosci 1992; 4: 981-992.

52. Lenoir M, Shnerson A, Pujol R. Cochlear receptor development in the rat with emphasis on synaptogenesis. Anat Embryol 1980; 160: 253-262.

53. Robertson D, Harvey AR, Cole KS. Postnatal development of the efferent innervation of the rat cochlea. J Comp Neurol 1989; 314: 367-382.

54. Karis A, Pata I, van Doorninck JH, Grosveld F, de Zeeuw Cl, de Caprona D, et al. Transcription factor GATA-3 alters pathway selection of olivocochlear neurons and affects morphogenesis of the ear. J Comp Neurol 2001; 429: 615-630.

55. Bell E, Lumsden A, Graham A. Expression of GATA-2 in the developing avian rhombencephalon. Mech Dev 1999; 84: 173-176.

56. Pandolfi PP, Roth ME, Karis A, Leonard MW, Dzierzak E, Grosveld FG, et al. Targeted disruption of the GATA3 gene causes severe abnormalities in the nervous system and in fetal liver haematopoiesis. Nat Genet 1995; 11: 40-44.

57. Ma Q, Chen Z, del Barco Barrantes I, de la Pompa JL, Anderson DJ. Neurogenin1 is essential for the determination of neuronal precursor for proximal cranial sensory ganglia. Neuron 1998; 20: 469-482.

58. Ma Q, Anderson DJ, Fritzsch B. Neurogenin 1 null mutant ears develop fewer, morphologically normal hair cells in smaller sensory epithelia devoid of innervation. J Assoc Res Otolaryngol 2000; 1: 129-143.

59. Tessier-Lavigne M, Goodman CS. The molecular biology of axon guidance. Science 1996; 274: 1123-1133.

60. Kury P, Gale N, Connor R, Pasquale E, Guthrie S. Eph receptors and ephrin expression in cranial motor neurons and the branchial arches of the chick embryo. Mol Cell Neurosci 2000; 15: 123-140.

61. Cowan CA, Yokoyama N, Bianchi LM, Henkemeyer M, Fritzsch B. EphB2 guides axons at the midline and is necessary for normal vestibular function. Neuron 2000; 26: 417-430.

62. Merchan-Perez A, Bartolome MV, Ibanez MA, Gil-Loyzaga P. Expression of Gap-43 in growing efferent fibers during cochlear development. ORL J Otorhinolaryngol Relat Spec 1993; 55: 208-210.
63. Knipper M, Zimmermann U, Rohbock K, Köpschall I, Zenner HP. Synaptophysin and GAP-43 proteins in efferent fibers of the inner ear during postnatal development. Dev Brain Res 1995; 89: 73-86.

64. Ginzberg RD, Morest DK. Fine structure of cochlear innervation in the cat. Hear Res 1984; 1: 109-127.

65. Skene JHP. Axonal growth-associated proteins. Annu Rev Neurosci 1989; 12: 127-156.

66. Emmerling MR, Sobkowicz HM, Levenick CV, Scott GL, Slapnick SM, Rose JE. Biochemical and morphological differentiation of acetylcholinesterase-positive efferent fibers in the mouse cochlea. J Electr Microsc Techn 1990; 15: $123-143$.

67. Simmons DD, Mansdorf NB, Kim JH. Olivocochlear innervation of inner and outer hair cells during postnatal maturation: evidence for a waiting period. J Comp Neurol 1996; 370: 551-562.

68. Pirvola U, Ylikoski J, Palgi J, Lehtonen E, Arumäe U, Saarma M. Brain-derived neurotrophic and neurotrophin-3 mRNAs in the peripheral target fields of developing inner ear ganglia. Proc Natl Acad Sci USA 1992; 89: 9915-9919.

69. Pirvola U, Arumäe U, Moshynakov M, Palgi J, Saarma M, Ylikoski J. Coordinated expression and function of neurotrophins and their receptors in the rat inner ear during target innervation. Hear Res 1994; 75: 131-144.

70. Schecterson LC, Bothwell M. Novel roles for neurotrophins are suggested by BDNF and NT-3 mRNA expression in developing neurons. Neuron 1992; 9: 449-463.

71. Schecterson LC, Bothwell M. Neurotrophin and neurotrophin mRNA expression in developing inner ear. Hear Res 1994; 73: 92-100.

72. Ylikoski J, Pirvola U, Moshnyakov M, Palgi J, Arumae U, Saarma M. Expression patterns of neurotrophin and their receptor mRNAs in the rat inner ear. Hear Res 1993; 65: 69-78.

73. Wheeler EF, Bothwell M, Schecterson LC, von Bartheld CS. Expression of BDNF and NT-3 mRNA in hair cells of the organ of Corti: quantitative analysis in developing rats. Hear Res 1994; 73: 46-56.

74. Ernfors P, Van De Water TR, Loring J, Jaenisch R. Complementary roles of BDNF and NT-3 in the auditory and vestibular development. Neuron 1995; 14: 1153-1164.

75. Wiechers B, Gestwa G, Mack A, Carroll P, Zenner HP, Knipper M. A changing pattern of brain-derived neurotrophic factor expression correlates with the rearrangement of fibres during cochlear development of rats and mice. $J$ 
Neurosci 1999; 19: 3033-3042.

76. Fritzsch B, Pirvola U, Ylikoski J. Making and breaking the innervation of the ear: neurotrophic support during ear development and its clinical implications. Cell Tissue Res 1999; 295: 369-382.

77. Fritzsch B, Siltos-Santiago I, Smeyne D, Fagan A, Barbacid $\mathrm{M}$. Reduction and loss of inner ear innervation in trkB and trkC receptor knock out mice: a whole mount DiI and SEM analysis. Aud Neurosci 1995; 1: 401-41.

78. Silos-Santiago I, Fagan AM, Garber M, Fritzsch B, Barbacid M. Severe sensory deficits but normal CNS development in newborn mice lacking trkB and trkC tyrosine kinase receptors. Eur J Neurosci 1997; 10: 2045-56.

79. Ivanov EA, Lazarov NE. Postnatal development of the afferent innervation of the mammalian cochlea. Biomed Rev 2012; 23: 37-52.

80. Ma Q, Fode C, Guillemot F, Anderson DJ. Neurogenin1 and neurogenin2 control two distinct waves of neurogenesis in developing dorsal root ganglia. Genes Dev 1999; 13: 1717-1728.

81. Whitlon DS, Zhang X, Kusakabe M. Tenascin-C in the cochlea of the developing mouse. J Comp Neurol 1999; 406: 361-374.

82. Fitzsimonds RM, Poo MM. Retrograde signaling in the development and modification of synapses. Physiol Rev 1998; 78: 143-70.

83. Zuo J, Treadaway J, Buckner TW, Fritzsch B. Visualization of alpha9 acetylcholine receptor expression in hair cells of transgenic mice containing a modified bacterial artificial chromosome. Proc Natl Acad Sci USA 1999; 96: 14100-14105.

84. Knipper M, Zimmermann U, Rohbock K, Kopschall I, Zenner HP. Expression of neurotrophin receptor trkB in rat cochlear hair cells at time of rearrangement of innervation. Cell Tissue Res 1996; 283: 339-353.

85. Fritzsch B, Siltos-Santiago I, Farinas I. The role of neurotrophic factors in regulating inner ear innervation. TINS 1997; 20: 159-164.

86. Sendtner M, Holtmann B, Kolbeck R, Thoenen H, Brade YA. Brain-derived neurotrophic factor prevents the death of motoneurons in newborn rats after nerve section. Nature 1992; 360: 757-779.

87. Sendtner M, Schmalbruch H. Stöckli KA, Carroll P, Kreutzberg GW, Thoenen $\mathrm{H}$. Ciliary neurotrophic factor prevents degeneration of motor neurons in mouse mutant progressive motor neuronopathy. Nature 1992; 358: 502-554.
88. Sendtner M, Stöckli KA, Thoenen H. Synthesis and location of ciliary neurotrophic factor in the rat sciatic nerve of the adult rat after lesion and during regeneration. $J$ Cell Biol 1992; 118:139-148.

89. Despres G, Hafidi A, Romand R. Immunohistochemical localization of nerve growth factor receptor in the cochlea and in the brainstem of the perinatal rat. Hear Res 1991; 52: 157-165.

90. Ivanov E. Postnatal development of the afferent and efferent innervation of the organ of Corti in the rat. Bulg Med 1994; 1-2: 10-16 (in Bulgarian).

91. Sher AE. The embryonic and postnatal development of the inner ear of the mouse. Acta Otolaryngol 1971; 265: 1-77.

92. Pujol R, Carlier E, Devigne C. Differential patterns of cochlear innervation during the development of the kittens. J Comp Neurol 1978; 117: 529-536.

93. Shnerson A, Devigne C, Pujol R. Age-related changes in the C57BL/6J mouse cochlea. II. Ultrastructural findings. Dev Brain Res 1982; 2: 77-78.

94. Fritzsch B, Nichols DH. DiI reveals a prenatal arrival of efferents at developing ears of mice. Hear Res 1993; 65: 51-60.

95. Bulankina AV, Moser T. Neural circuit development in the mammalian cochlea. Physiology 2012; 27: 100-112.

96. Sobkowicz HM, Slapnick SM. The efferents interconnecting auditory inner hair cells. Hear Res 1994; 75: 81-92.

97. Liberman MC. Efferent synapses in the inner hair cell area of the cat cochlea: an electron microscopic study of serial sections. Hear Res 1980; 3: 189-204.

98. Elgoyen AB, Johnson DS, Boulter J, Vetter DE, Heinemann S. $\alpha 9$ : an acetylcholine receptor with novel pharmacological properties expressed in cochlear hair cells. Cell 1994; 79: 705-715.

99. Safieddine S, Bartolami S, Wenthold RJ, Eybalin M. Pre- and postsynaptic m3 muscarinic receptor mRNA in the rodent peripheral auditory system. Mol Brain Res 1996; 40: 127-135.

100. Kikuchi K, Hilding D. The development of the organ of Corti in the mouse. Acta Otolaryngol 1965; 60: 207-222.

101. Pujol R, Carlier E. Cochlear synaptogenesis after sectioning the efferent bundle. Dev Brain Res 1982; 3: 151-154.

102. Pujol R, Zajic G, Dulon D, Raphael Y, Altschuler RA, Schacht J. First appearance and development of motile properties in outer hair cells isolated from guinea-pig cochlea. Hear Res 1991; 57: 129-141. 
103. Lavigne-Rebillard M, Pujol R. Hair cell innervation in the fetal human cochlea Acta Otolaryngol (Stockh) 1988; 105: 398- 402.

104. Pujol R, Lavigne-Rebillard M, Lenoir M. Development of sensory and neural structures in the mammalian cochlea. In: R Fay and AN Popper, editors. Development of the Auditory System. Springer, New York, 1994: 146-192.

105. Pujol R, Carlier E, Lenoir M. Ontogenetic approach to inner and outer hair cells functions. Hear Res 1980; 2: 423-430.

106. Simmons DD, Manson-Gieseke L, Hendrix TW, McCarter S. Reconstructions of the efferent fibers in the postnatal hamster cochlea. Hear Res 1990; 49: 127-140.

107. Bruce LL, Christensen A, Warr WB. Postnatal development of efferent synapses in the rat cochlea. J Comp Neurol 2000; 423: 532-548.

108. Pujol R, Lavigne-Rebillard M. Early stages of innervation and sensory cell differentiation in the human organ of Corti. Acta Otolaryngol (Stockh) 1985; 423: 43-50.

109. Cole KS, Robertson D. Early efferent innervation of the developing rat cochlea studied with a carbocyanine dye. Brain Res 1992; 575: 223-230.

110. Simmons DD. A transient afferent innervation of outer hair cells in the postnatal cochlea. Neuroreport 1994; 5:1309-1312.

111. Roux I, Wersinger E, McIntosh JM, Fuchs PA, Glowatzki E. Onset of cholinergic efferent synaptic function in sensory hair cells of the rat cochlea. J Neurosci 2011; 31: 15092-15101.

112. Glowatzki E, Fuchs PA. Cholinergic synaptic inhibition of inner hair cells in the neonatal mammalian cochlea. Science 2000; 288: 2366-2368.

113. Morley BJ, Simmons DD. Developmental mRNA expression of the alpha10nicotinic acetylcholine receptor subunit in the rat cochlea. Brain Res Dev Brain Res 2002; 139: 87-96.
114. Katz E, Elgoyhen AB, Gomez-Casati ME, Knipper M, Vetter DE, Fuchs PA, et al. Developmental regulation of nicotinic synapses on cochlear inner hair cells. J Neurosci 2004; 24: 7814-7820.

115. Simmons DD. Development of the inner ear efferent system across vertebrate species. J Neurobiol 2002; 53 : 228-250.

116. Role LW, Berg DK. Nicotinic receptors in the development and modulation of CNS synapses. Neuron 1996; 16: 1077-1085.

117. Marcotti W, Johnson SL, Rusch A, Kros CJ. Sodium and calcium currents shape action potentials in immature mouse inner hair cells. J Physiol 2003b; 552: 743-761.

118. Kros CJ, Ruppersberg JP, Rusch A. Expression of a potassium current in inner hair cells during development of hearing in mice. Nature 1998; 394: 281-284.

119. Walsh EJ, McGee J, McFadden SL, Liberman MC. Longterm effects of sectioning the olivocochlear bundle in neonatal cats. J Neurosci 1998; 18: 3859-3369.

120. Warren EH, Liberman MC. Effects of contralateral sound on auditory-nerve responses. II. Dependence on stimulus variables. Hear Res 1989; 37: 105-121.

121. Zheng XY, Henderson D, McFadden SL, Ding DL, Salvi RJ. Auditory nerve fiber responses following chronic cochlear de-efferentation. J Comp Neurol 1999; 406: 72-86.

122. Bergeron AL, Schrader A, Yang D, Osman AA, Simmons DD. The final stage of cholinergic differentiation occurs below inner hair cells during development of the rodent cochlea. J Assoc Res Otolaryngol 2005; 6: 401-415.

123. Housley GD, Ashmore JF. Direct measurement of the action of acetylcholine on isolated outer hair cells of the guinea pig cochlea. Proc R Soc Lond B Biol Sci 1991; 244: 161-167. 